\title{
An Effect of Electric Current Variations and Wire Feed Rate on Low Carbon Steels Toward Tensile Strength on The Result of Gas Metal Arc Welding
}

\author{
Taufik Hardiansyah ${ }^{1, *}$, Moch Rofi Imron $^{1}$, Johan Handoko ${ }^{1}$, Solichin ${ }^{1}$, Abdul Qolik $^{1}$ \\ ${ }^{1}$ Department of Mechanical Engineering, Faculty of Engineering, State University of Malang, 65155 \\ Malang, Indonesia
}

\begin{abstract}
The purpose of this study was to find out the tensile strength of GMAW welded carbon steel with electric current variation and wire feed rate. The research method used was experimental research with electric current variation of $120 \mathrm{~A}, 140 \mathrm{~A}$, and $160 \mathrm{~A}$ and variation of wire feed rate $4 \mathrm{~m} / \mathrm{min}$ and $5 \mathrm{~m} / \mathrm{min}$. The tensile strength test of sample was done by ASTM E8 / E8M-09 test standard. The result showed that the electric current variation and wire feed rate in welding of carbon steel with GMAW welding gave effect on the value of tensile strength which was varied. The electric current of $120 \mathrm{~A}$ and the wire feed rate of $4 \mathrm{~m} / \mathrm{min}$ obtained the highest tensile strength of $52.67 \mathrm{kgf} / \mathrm{mm}^{2}$ and welding with electric current of $120 \mathrm{~A}$ and wire feed rate of $5 \mathrm{~m} / \mathrm{min}$ obtained the lowest tensile strength of $48.33 \mathrm{kgf} / \mathrm{mm}^{2}$.
\end{abstract}

\section{Introduction}

The production process, especially in the field of construction machinery, shipping, bridges, steel frame, pipeline, and railways, are often encountered in the connection process. Nowadays, the most widely used in grafting technique is the welding process. Utilization of the welding technique is based because the building or machine made with the welding process becomes lighter and the implementation process is also simpler, so that it indirectly affects on the emphasis on production costs because it is cheaper. The welding process is not the main purpose of construction, but it is a medium to achieve a better manufacturing economy. Therefore, in the process of manufacturing, the design of welding and welding process should really pay attention to the suitability between the welding properties with the usefulness of construction and the circumstances surrounding it [1].

In GMAW welding often found the influence of electric current and wire feed rate to the good quality of welding. With the difference or comparison of electric current and wire feed rate, it can cause the different properties of welding results. To deepen the penetration, it can be done by increasing the current strength. The higher the wire feed rate then makes the size of the weld bead narrowed, shallow penetration, low bead gain. So that with the

\footnotetext{
*Corresponding author: taufikhardiansyah82@gmail.com
} 
wire feed rate adjustment in accordance with the electric current will affect the structure formed in the HAZ (Heat Affected Zone) and the parent metal so that the effect also on the physical and mechanical properties of welding [1] .

One material that is widely used in industry and becomes the main ingredient in the process of clarity is carbon steel. Carbon steel is commonly used for manufacturing industries because it has a relatively cheap price, easy to do fabrication process, and has good welding properties. Research on carbon steel welding becomes very important to be done for the advancement of the world of manufacturing industry. In addition, in the welding process, there are also some problems, especially in steel welding. Sensitivity to brittle fracture is one of the major problems in steel and affects the welding results so it needs to be measured in advance. One way to measure the strength against a fault is to do a tensile test. Therefore, the purpose of this study was to analyze the effect of variations in current strength and wire feed rate on low carbon steel to tensile strength of GMAW welding results.

\section{Methods}

The method used in this study is an experimental design. This study aimed to determine whether there is an influence of the electric current variation and wire feed rate on carbon steel to tensile strength of GMAW welding results. This research used two independent variables which usually the second free variable called moderator variable. According to [2]. not all experiments in a study using a similar treatment or one level. Sometimes things that may affect the course of the experiment are also given, so there will be a combination of two or more treatments. The design used in this research was factorial $3 \times 2$ which was three variations of electric current and two variations of wire feed rate. And the dependent variable in this research was the result of tensile strength due to variation of welding treatment.

Table 1. Research Design

\begin{tabular}{|c|c|c|c|c|}
\hline & & Electri & & \\
\hline & & $120 \mathrm{~A}$ & $140 \mathrm{~A}$ & $160 \mathrm{~A}$ \\
\hline & & $\mathrm{X}_{1.1}$ & $\mathrm{X}_{2.1}$ & $\mathrm{X}_{3.1}$ \\
\hline$\underset{8}{8}$ & $4 \mathrm{~m} / \mathrm{min}$ & $\mathrm{X}_{1.2}$ & $\mathrm{X}_{2.2}$ & $X_{3.2}$ \\
\hline & & $\mathrm{X}_{1.3}$ & $\mathrm{X}_{2.3}$ & $X_{3.3}$ \\
\hline & & $\mathrm{Y}_{1.1}$ & $Y_{2.1}$ & $\mathrm{Y}_{3.1}$ \\
\hline$\stackrel{0}{=}$ & $5 \mathrm{~m} / \mathrm{min}$ & $\mathrm{Y}_{1.2}$ & $\mathrm{Y}_{2.2}$ & $Y_{3.2}$ \\
\hline & & $Y_{1.3}$ & $\mathrm{Y}_{2.3}$ & $Y_{3.3}$ \\
\hline
\end{tabular}

In this study, the number of specimens used by researchers was 18 specimens of tensile test, with each variable represented by three specimens. The type of groove used in this study was open $\mathrm{V}$ groove. The steps of specimen formation for welding include cutting of specimens with the length of $100 \mathrm{~mm}$, width $90 \mathrm{~mm}$, and $5 \mathrm{~mm}$ thickness of 12 pieces, then open $\mathrm{V}$ compound with a slope angle of $50^{\circ}$ by using a grinding machine. The formation of test specimens was carried out after welding. In the formation of this test specimen used the cold working procedure in order to prevent structural changes in the welded specimen. The steps for tensile test formation, i.e. cutting of specimens that have been done by using chainsaws and then the formation of tensile test specimens using Frais machine. The size 
and shape of the specimen adopted the established standard ASTM E8 / E8M-09, as shown in Figure 1. The research flow diagram is shown in Figure 2.

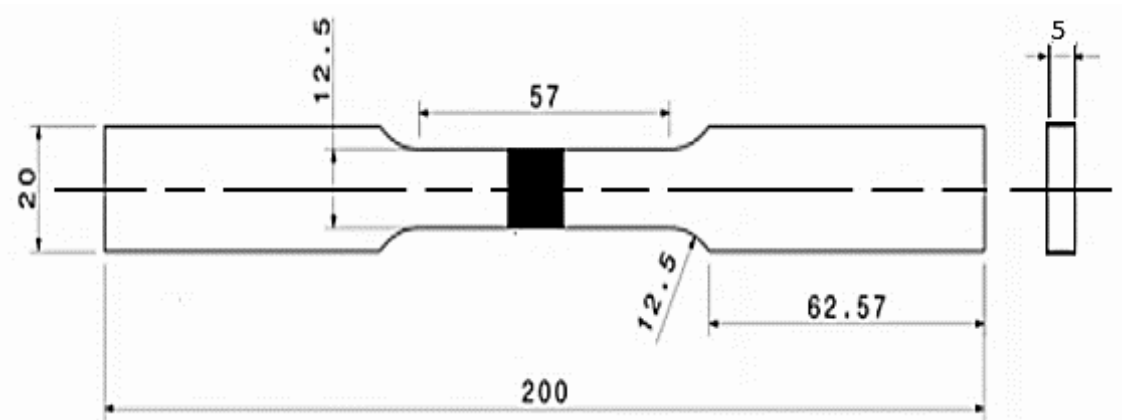

Fig. 1. Tensile Test Specimen ASTM E8/E8M-09

Source: ASTM E8/E8M-09 standard test methods for tension testing of metallic material

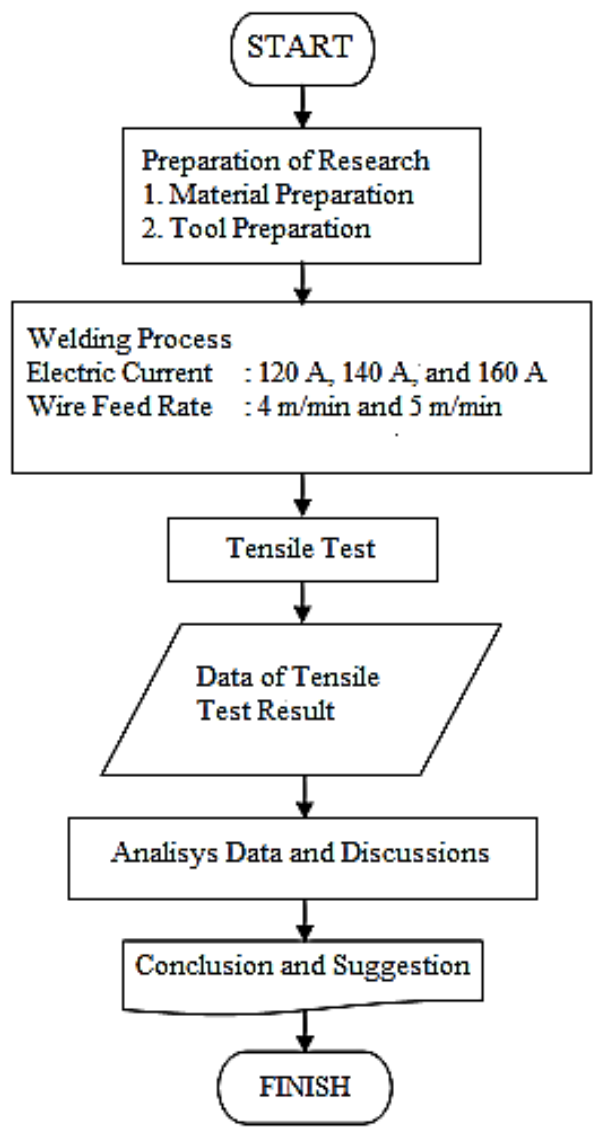

Fig. 2. Research Flow Diagram 


\section{Results and Discussion}

The tensile test results of the various treatment variations are shown in Figure 3. The tensile test results with variations in electric current at the wire feed rate of $4 \mathrm{~m} / \mathrm{min}$ had the lowest tensile strength average number of 160 A specimens of $48.62 \mathrm{kgf} / \mathrm{mm} 2$, while the 120 A specimens had the average tensile strength of $52,67 \mathrm{kgf} / \mathrm{mm}^{2}$ and tensile test result with variation of electric current at wire feed rate $5 \mathrm{~m} / \mathrm{min}$ had the lowest average tensile strength value of 120 A specimen of $48,33 \mathrm{kgf} / \mathrm{mm} 2$, while 140 A specimen had highest tensile strength of $51,86 \mathrm{~kg} / \mathrm{mm}^{2}$. The average result of the research can be seen in the Figure 3.

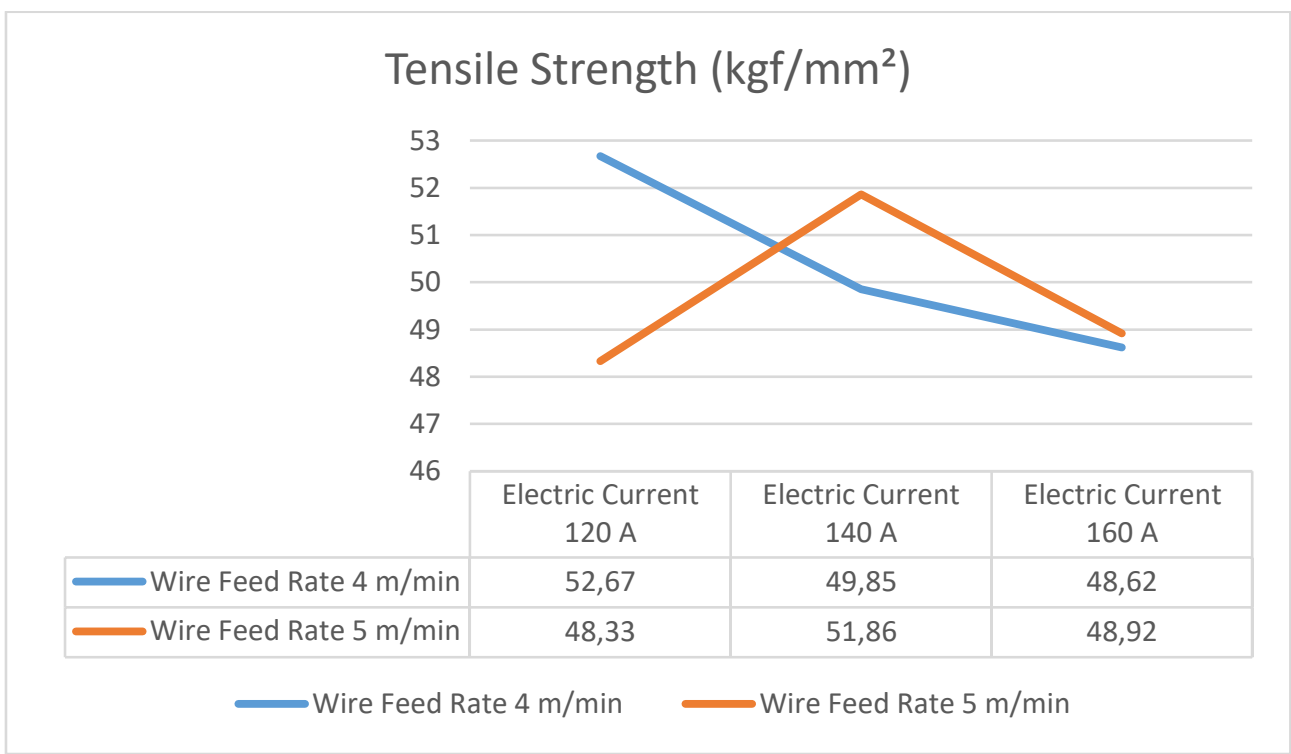

Fig. 3. Graph of Tensile Strength Results on Welding of Carbon Steels with Electric Current Variations (120 A, $140 \mathrm{~A}, \& 160 \mathrm{~A})$ dan Wire Feed Rate $(4 \mathrm{~m} / \mathrm{min} \& 5 \mathrm{~m} / \mathrm{min}$ )

From the results above, it can be seen that there is a difference in the value of tensile strength resulting from changes in current and wire feed rate used. In 160 A electric currents welding provided a low tensile strength, this occurred because the use of $160 \mathrm{~A}$ current with the use of wire feed rate of $4 \mathrm{~m} / \mathrm{min}$ caused the welding area became so widened because the heat input was too large and the arc became unstable. This had an impact on the speed of melting of the filler which was so quickly so that it was obtained widening rigidity and less evenly and so deep penetration, therefore it will get the results of welding that was less strong and has a low tensile strength.

The smaller the wire feed rate $(4 \mathrm{~m} / \mathrm{min})$ then the current used was also small (120 A). By this condition then the tensile strength of the welding became better. Due to the lower wire feed rate the heat input was stable, the penetration deepened and the speed of melting the metal became stable. The melting of the filler and the parent metal required sufficient heat energy and stable no shortage or excess heat energy. The presence of a sufficient amount of heat input to melt the filler metal and a good parent metal would be capable of producing a really strong welding joint, so that when tensile testing was performed, the 
specimen did not fracture in the welded joint region but was broken in the weld area or on the parent metal.

The result of research conducted by [3] gets a result where the use of strong current of 120 A get good welding result and have the best tensile strength level compared with other electric current variations. This is because with the use of electric current of the $120 \mathrm{~A}$ was rated to produce sufficient heat input to melt the weld metal and the parent metal which will result in a uniform welding joint. At the usage of welding current $160 \mathrm{~A}$ and wire feed rate $4 \mathrm{~m} / \mathrm{min}$, tensile strength of welding result decrease. This is because the arc spark becomes larger so that the heat input is too large and the cooling will slowly occur the enlargement of grain shape. Large grain shape will cause a decrease in the strength of a material. This is in line with the theory put forward by [4] where the material will have high strength if it has small grain boundaries. Because the small grain shape is able to withstand the movement of the dislocations so as to possess great strength.

As well as in the difference in use of the wire feed rate of $4 \mathrm{~m} / \mathrm{min}$ and $5 \mathrm{~m} / \mathrm{min}$ where the use of a wire feed rate of $4 \mathrm{~m} / \mathrm{min}$ on average has higher tensile strength at each of the electric current variations of $120 \mathrm{~A}, 140 \mathrm{~A}$, and $160 \mathrm{~A}$ compared with the use of a wire feed rate of $5 \mathrm{~m} / \mathrm{min}$. This is in line with the research conducted by [5] which also found the result that low wire feed rate and suitable electric current can produce good welding quality and have high tensile strength, so the higher wire feed rate used, the lower the tensile strength of welding results are formed, vice versa if the lower wire feed rate used then the higher tensile strength of welding results are formed.

This is in line with the results of research conducted by [6] which obtained the result that there is a significant influence due to wire feed rate variation of the welding strength results. Thus, the higher the speed of wire feed rate used, the welding results will experience the tensile strength of the specimen will be lower due to the inclusion of heat during welding is reduced. To get the tensile strength of the welding is high and good then there must be a balance or a straight comparison between the electric current and wire feed rate. Where good welding results do not occur fracture in the welded joint region but subjected to fractures in the HAZ region or to the parent metal. This is also in line with research conducted which also obtained the result that the lowest wire feed rate variations that have the best quality welding results compared with the higher variations.

In addition to the use of wire feed rate, the use of electric currents is also considered to greatly affect the welding strength. This is in accordance with research conducted by [4] obtained the results that variations in electric current in aluminum welding 5083 position $1 \mathrm{G} \mathrm{GMAW} \mathrm{welding} \mathrm{effect} \mathrm{on} \mathrm{tensile} \mathrm{strength.} \mathrm{The} \mathrm{results} \mathrm{of} \mathrm{suitable} \mathrm{welding} \mathrm{of} \mathrm{suitable}$ currents can produce excellent welding quality and have a high average tensile strength.

From the three current treatments applied, the researcher took a strong variable electric current $120 \mathrm{~A}$ for the deeper assessment of the influence of variations in current strength and wire feed rate on tensile strength of welding results. As in the discussion other than electric currents, wire feed rate also gave effect on the tensile strength of welding results. In the welding process current $120 \mathrm{~A}$ with wire feed rate of $4 \mathrm{~m} / \mathrm{min}$, it produced the tensile strength of $52.67 \mathrm{kgf} / \mathrm{mm}^{2}$. While in the welding process current $120 \mathrm{~A}$ with wire feed rate $5 \mathrm{~m} / \mathrm{min}$ tensile strength produced by $48.33 \mathrm{kgf} / \mathrm{mm}^{2}$. This indicated that there was a decrease in the welding result using the same current at the wire feed rate of $4 \mathrm{~m} / \mathrm{min}$ and the wire feed rate of $5 \mathrm{~m} / \mathrm{min}$. Where the results of welding using a wire feed rate of $4 \mathrm{~m} /$ min had a better quality and a high tensile strength.

This occurred because at the time of welding with a current of $120 \mathrm{~A}$ and wire feed rate of $4 \mathrm{~m} / \mathrm{min}$, there was a sufficient heat input resulting in melting filler and parent metal 
evenly, while at welding with a current of $120 \mathrm{~A}$ and wire feed rate $5 \mathrm{~m} / \mathrm{min}$, there was an insufficient heat input so that it cannot melt the filler and the parent metal perfectly causing the welding result was less mature and uneven melting. This was very influential on the quality of welding results. This is in accordance with the statement of [1] in which electric currents have a great influence in the process of penetration and strengthening. The smallest current results in a low penetration and reinforcement, and if the current being used is too large it will produce pear-shaped beads and will be easy to crack heat.

From all of the exposure of welding results with the variation used can be concluded that the use of wire feed rate $4 \mathrm{~m} / \mathrm{min}$ is better to be applied in the welding process compared with the use of wire feed rate $5 \mathrm{~m} / \mathrm{min}$. Moreover, the strongest welding current that is best applied to the wire feed rate of $4 \mathrm{~m} / \mathrm{min}$ is 120 A due to the application of both parameters obtained the results of the quality of welding and has the highest tensile strength of welding results compared with the application of other parameters.

\section{Conclusion}

The results of research and discussion can be concluded that the variation of current and wire feed rate of carbon steel welding by using GMAW welding has an effect on tensile strength. The welding with electric current of $120 \mathrm{~A}$ and the wire feed rate of $4 \mathrm{~m} / \mathrm{min}$ give the highest tensile strength of $52.67 \mathrm{kgf} / \mathrm{mm}^{2}$ and the welding with electric current of $120 \mathrm{~A}$ and the $5 \mathrm{~m} / \mathrm{min}$ wire feed rate provide the lowest tensile strength of $48.33 \mathrm{kgf} /$ $\mathrm{mm}^{2}$.

The suggestion that can be given to improving the GMAW welding result is GMAW welding can be done with an electric current of $120 \mathrm{~A}$ and wire feed rate $4 \mathrm{~m} / \mathrm{min}$. If the carbon steel welding process is done then fine-tuning the current and wire feed rate properly and correctly so that melting of the weld metal occurs well and the required heat input is sufficient.

\section{References}

1. Wiryosumarto. Harsono \& Okumura. Toshie.,. Jakarta: PT. Pradnya Paramita. (1996)

2. Nazir. Moh,, Edisi Keenam. Bogor Selatan: PT. Ghalia Indonesia. (2005)

3. Suyono. Eko Hendry, Irawan. Yudi Surya, dan Purnowidodo. Anindito, Jurnal Rekayasa Mesin, 2 (2), 137-144 (2011)

4. Laksono. Wahyu Anjar Setyo., Solichin., \& Yoto, Jurnal Teknologi dan Kejuruan. 40 (1). 21-30 (2017)

5. Susanto. Wahyu E \& Prasetio. Dwi J, Jurnal Teknik Mesin, 6 (1), 11-20 (2017) 